\title{
Approach To The Treatment of Spontaneous Hemothorax Due To The Anticoagulant Therapy: Report of Three Cases
}

\author{
Antikoagülan Tedaviye Bağı Gelişen Spontan Hemotoraksta Tedavi Yaklaşımı: \\ Üç Olgu Sunumu
}

\author{
Yener Aydın', Murat Aydın², Hasan Kaynar³ Atila Türkyılmaz', Atilla Eroğlu' \\ 'Department of Thoracic Surgery, Ataturk University, Medical Faculty, Erzurum, Turkey \\ ${ }^{2}$ Yozgat State Hospital, Department of Cardiovasculer Surgery, Yozgat, Turkey \\ ${ }^{3}$ Department of Chest Diseases, Ataturk University, Medical Faculty, Erzurum, Turkey
}

\begin{abstract}
Bleeding is the most important complication of the anticoagulant therapy. The annual risk of bleeding in patients taking warfarin such as; fatal episode is approximately $1 \%$, major episode is $6.5 \%$, and minor bleeding is $21.8 \%$. A small number of hemothorax cases that formed due to anticoagulant therapy, have been reported in the literature. Shock and mortality may be developed in severe bleeding. Hematoma and trapped lung may be occurred, if hemothorax not adequately discharge. When the hemothorax is seen, anticoagulant therapy should be terminated immediately and pleural range to be discharged. In present study, three cases were presented with the literature, which had detected spontaneous hemothorax due to the anticoagulant therapy during the warfarin therapy.
\end{abstract}

Keywords: Anticoagulation, spontaneous hemothorax, treatment

Aplication: 14.09.2011

Accepted: 14.11 .2011

\section{Özet}

Antikoagülan tedavinin en önemli komplikasyonu kanamadır. Warfarin alan hastalarda yıllık kanama riski; fatal epizod yaklaşık \%1, major epizod \%6.5, minör kanama ise \%21.8'dir. Literatürde antikoagülan tedaviye bağlı az sayıda spontan hemotoraks olgusu bildirilmiştir. Kanama şiddetli ise şok ve mortalite gelişebilir. Hemotoraks yeterli şekilde boşaltılmazsa hematom ve hapsolmuş akciğer oluşumu riski taşımaktadır. Hemotoraks görüldügünde antikoagülan tedavi hemen sonlandırımalı ve plevral aralık boşaltılmalıdır. Bu çalışmada warfarin tedavisine bağlı üç olguda gelişen spontan hemotoraks olgusu literatür bilgileri ışığında sunuldu.

Anahtar Kelimeler: Antikoagülanlar; hemotoraks, tedavi

\section{Introduction}

The hemothorax that occurred without any specific trauma, denominated spontaneous or nontraumatic hemothorax. Although spontaneous hemothorax rarely than traumatic hemothorax it have lots of causations. The main causation of the spontaneous hemothorax is getting anticoagulant and neoplasm. Rare reasons are vascular ruptures such as aortic dissection and arteriovenous fistulas, pulmonary infarction, rupture of pleural adhesions due to pneumothorax, pleural endometriosis, haemophilia, thrombocytopenia and the other conditions that change the homeostasis and idiopathic situations ${ }^{1}$. The annual risk of bleeding in patients taking warfarin 
such as; fatal episode is approximately $1 \%$, major episode is $6.5 \%$, and minor bleeding is $21.8 \%{ }^{2}$. It is classified as major if it is intracranial or retroperitoneal and hospitalization or transfusion can be required or it can cause directly mortality ${ }^{3}$. Although the anticoagulant therapy has frequently using, a small number of cases have been reported with hemothorax due to anticoagulant therapy in the literature. In this study, the three cases are presented, that have detected spontaneous hemothorax due to warfarin therapy.

\section{Case I}

A 26-year-old male patient, which had detected deep venous thrombosis in Doppler ultrasound application for right leg pain. Warfarin treatment was started. Left chest pain was occurred in the eight day of the treatment. In physical examination revealed reduced breath sounds in left lung. Posterior-anterior (PA) chest radiography revealed pleural fluid in left lung. Contrasted thorax computed tomography (CT) viewed $6 \mathrm{~cm}$ thickness pleural effusion in the left thorax and formation of fibrotic bands and linear atelectasis in the basalis of left lung. No embolism was observed. Haemoglobin was found $13.4 \mathrm{~g} / \mathrm{dL}$ (normal values range from 14 to $16 \mathrm{~g} / \mathrm{dL}$ ), international normalized ratio (INR) was found 12.48 in laboratory examination. Warfarin was stopped immediately. Two units of fresh frozen plasma were transfused. K vitamin supplement were given. Tube thoracostomy was applied second day. 700cc hemorrhagic drainage was observed. The fluid was completely drained through the chest drain. Additional process did not apply. After third day, the thorax drain was ended and the patient was discharged.

\section{Case II}

A 50-year-old male patient was admitted to our clinic with complaint of chest pain and coughing. He had a history of aortic and mitral valve replacement six mounts ago. Patients were receiving warfarin. PA chest radiography revealed pleural fluid. Haemoglobin was found $11.4 \mathrm{~g} / \mathrm{dL}$. INR was found 2.8 in laboratory examination. Warfarin was ended immediately. $\mathrm{K}$ vitamin was given. Two units of fresh frozen plasma were transfused. Tube thoracostomy was applied six hour later. 600cc drainage was observed. Streptokinase is administered within the pleural hematoma. After the third day of tube thoracostomy, streptokinase (150.000 IU) was diluted in $100 \mathrm{ml}$ of saline and applied to the intrapleural space through the thorax tube during three days. After the intrapleural fibrinolytic treatment (IPFT), it was detected that the decreasing pleural thickening and adhesion with the resolution of the clots in the pleural range. The patient was discharged without need of any other treatment.

\section{Case III}

A 50-year-old male patient admitted to our clinic with complaint of right chest pain and dyspnea. He had a history of coronary bypass surgery and mitral valve replacement one year ago. INR was detected as 3.5 and haemoglobin was detected as $12.6 \mathrm{~g} / \mathrm{dL}$ in patient taking warfarin. Thorax CT revealed pleural fluid and extensive pleural thickening. Also warfarin was discontinued immediately. $\mathrm{K}$ vitamin was given and three units of fresh frozen plasma were transfused. Right tube thoracostomy was applied one day later. $800 \mathrm{cc}$ drainage was observed. Streptokinase (150.000 IU) was diluted in 100 $\mathrm{ml}$ of saline and applied to the intrapleural space through the thorax tube during three days as case 2. However the decreasing pleural thickening and adhesion could not obtained with the resolution of the clots in the pleural range. Decortication was suggested in this case. But, the patient was not accepted surgery.

\section{Discussion}

The complication of the anticoagulant therapy for the pulmonary embolism is the one of the most common known causes of spontaneous hemothorax ${ }^{4}$. There have well documented 20 cases with spontaneous hemothorax due to the anticoagulant therapy ${ }^{5}$. Rostant et al ${ }^{6}$. Were reported 11 cases with hemothorax due to the anticoagulant therapy complication. The five of the reported cases had a history of only heparin usage, four had a history of heparin and warfarin usage, and two had a history of only warfarin usage. They reported that the hemothorax was occurred usually 4 to 7 day after the an- 
ticoagulant theraphy. Usually dosage was in the therapeutic range in these patients and hemothorax was found in the side of pulmonary embolism. However, recently, spontaneous hemothorax cases were reported due to the low molecular weight heparins ${ }^{4,7}$. Half of enoxaparine associated major bleeding complications had seen after the third day of theraphy ${ }^{8,9}$. We detected three cases with hemothorax due to oral anticoagulant theraphy in our study. One of the patients had a history of deep venous thrombosis and two of them had artificial valve replacement history.

Figure 1: Posteroanterior chest radiography of case 1 showing pleural fluid in left lung.

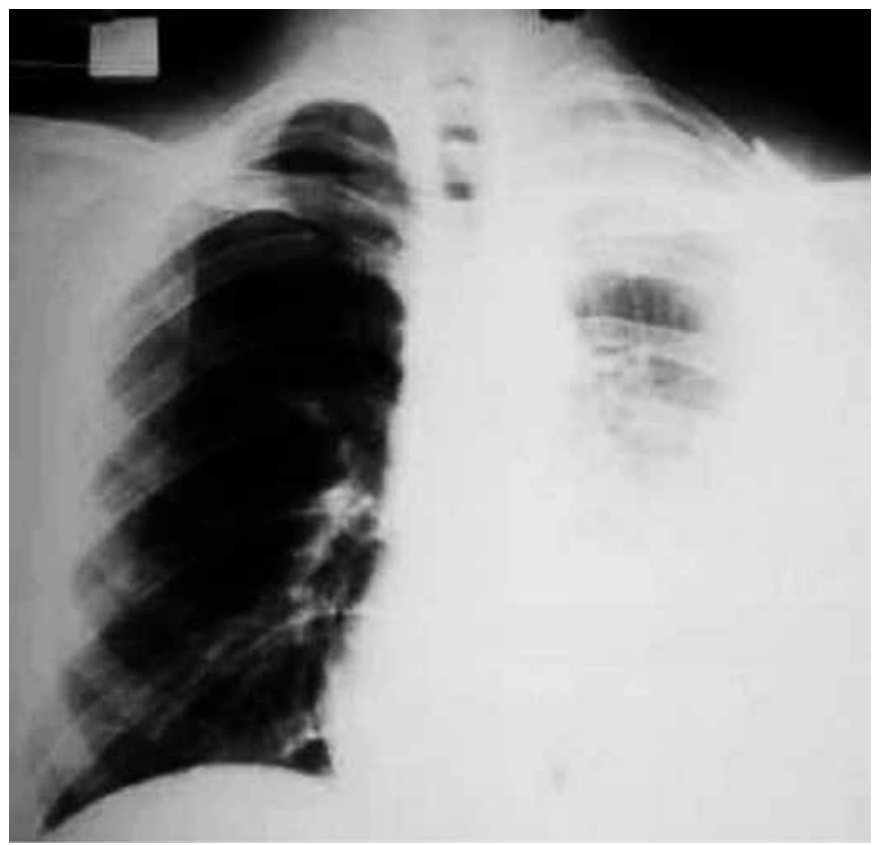

The anticoagulation effects of warfarin can be reversed by four ways. These are; end the treatment; $K$ vitamin replacement; infusion of fresh frozen plasma (FFP); and infusion of concentrated thrombotic factors ${ }^{2}$. Usually the effects are reversed after 3-5 days ending of the warfarin theraphy. Intravenous $\mathrm{K}$ vitamin provides normal levels of INR at 6-8 hours ${ }^{2}$. It can be too late for life threatening conditions. Especially in patients with 4-5 INR levels, FFP application at the dose of $15 \mathrm{ml} / \mathrm{kg}$ can be reversed the antithrombotic effects ${ }^{2}$.

Mortality and morbidity rates are too high in hemothorax that developed due to anticoagulant theraphy for the pulmonary embolism and the four of the reported 20 case was died ${ }^{5}$. Rupture of pulmonary infarct should be suspected when the circulatory and respiratory failure with unilateral pleural effusion occurred suddenly after the 7-10 days from the anticoagulant theraphy in the patients with suspected or precised pulmonary embolism ${ }^{10}$. There was deep venous thrombosis in our case and any pulmonary embolism was not detected. Hemothorax was occurred in eighth day in this case.

Successful treated cases were reported with thorasynthesis or tube thoracostomy in literature ${ }^{11-13}$. Promisloff ${ }^{11}$ described the tube drainage without surgical exploration applied. Dimitri12 could not be detected pathology and bleeding focus with thoracoscopic exploration after tube thoracostomy in a patient with massive idiopathic hemothorax. Yung et al. ${ }^{13}$ were discharged two liters of blood to the pleural space with thoracostomy in a case with spontaneous hemothorax. However they could not be detected bleeding focus and patient treated with thorax tube.

Figure 2: Thorax CT revealed showing pleural fluid and extensive pleural thickening of case 3 .

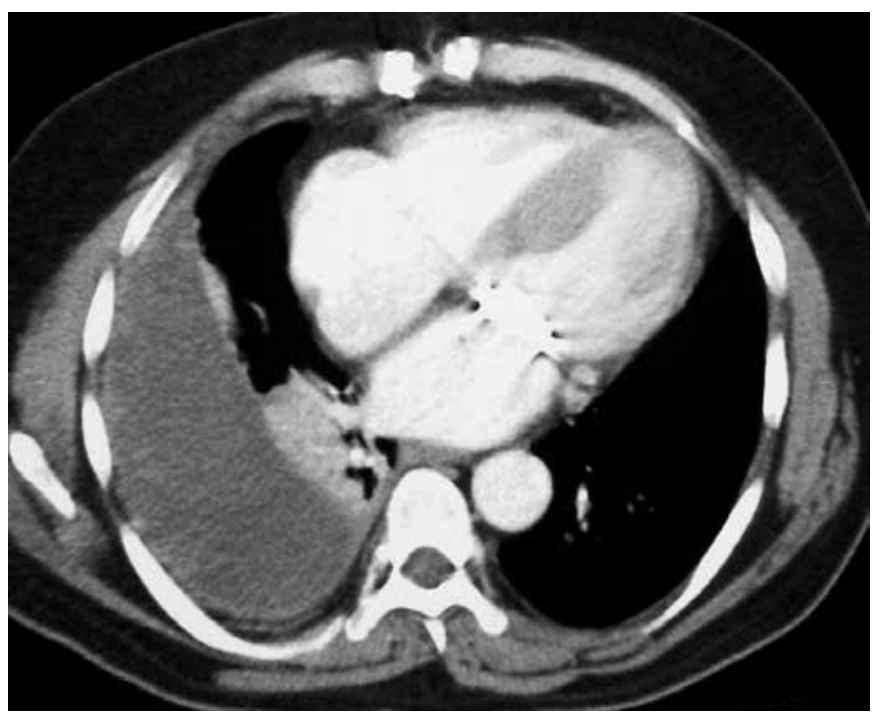

Clotted hemothorax have seen approximately $5-30 \%$ of the hemothorax cases and approximately $40 \%$ advanced surgical application is required in these cases due to intrapleural collections, empyema or fibrothorax ${ }^{5,14}$. Addi- 
tional tube application is ineffective for retained hemothorax because of clotted blood and loculations ${ }^{15}$. Both aggressive and conservative therapies were advocated in clotted hemothorax treatment. Although thoracotomy is effective application, recently minimally invasive approaches is preferred.

Recently, video-assisted thoracoscopic surgery (VATS) is accepted as an appropriate treatment in clotted hemothorax ${ }^{16}$.

Fibrinolytic with streptokinase was reported in lots of

\section{References}

1. Estarriol MH, Castillo LAA, Padró XB, Rispau AP, Garay MR, Goday MR. Bilateral Hemothorax Secondary to Combined Antiplatelet Therapy With Clopidogrel and Acetylsalicylic Acid. Arch Bronconeumol. 2006; 42: 307-9.

2. Makris M. Management of excessive anticoagulation or bleeding. Semin Vasc Med 2003; 3: 279-84.

3. Levine MN, Raskob G, Hirsh J. Hemorrhagic complications of long term anticoagulant therapy. Chest 1989; 95 (suppl): 26S-35S.

4. Bircan HA, Sahin U, Akkaya A. Spontaneous hemothorax due to ruptured pulmonary infarction after anticoagulation with enoxaparin: a case report. Respiratory 2006; 8: 33-36.

5. Ali HA, Lippmann M, Mundathaje U, Khaleeq G. Spontaneous Hemothorax. Chest 2008; 134; 1056-1065.

6. Rostand RA, Feldman RL, Block ER. Massive hemothorax complicating heparin anticoagulation for pulmonary embolus. South Med J 1977; 70: 1128-1130.

7. Mrug M, Mishra PV, Lusane HC, Cunnigham JM, Alpert MA. Hemothorax and retroperitoneal hematoma after anticoagulation with enoxaparin. South Med J 2002; 95: 936-938.

8. Noble S, Peters DH, Goa KL. Enoxaparin. A reapprasial of its pharmacology and clinical applications in the prevention and treatment of thromboembolic disease. Drugs 1995;49: 388-410.

9. Antman EM, McCabe CH, Gurfinkel EP, Turpie AG, Berning PJ, Salein $D$, et al. Enoxaparin prevents death and cardiac ischemic events in unstable angina/non-Q-wavemyocardial infarction. Results of theThrombolysis in Myocardial Infarction (TIMI) 11B Trial. Circulation 1999; 100: 1593-1601. case and it was determined as an effective option in reviews. Fibrinolysis achievement rate was found as $92 \%$ in a multicentre study ${ }^{17}$.

In conclusion, massive hemothorax is rarely situation in patient that gets oral anticoagulant theraphy. However hemothorax may be occurred in patients with high levels of INR. Anticoagulation associated hemothorax theraphy must be focused at the correction of coagulopathy. Ending of anticoagulant treatment must be the first step and tube thoracostomy must be applied. Operation decision and timing is dependent on individual foundations.

10. Wick MR, Ritter JH, Schuller D. Ruptured pulmonary infarction: a rare, fatal complication of thromboembolic disease. Mayo Clin Proc 2000; 75: 639-642.

11. Promisloff RA, Friehling J. Spontaneous hemothorax without pneumothorax. Clin Notes Respir Dis 1982; 21: 13-14.

12. Dimitri WR. Massive idiopathic spontaneous hemothorax: case report and literature review. Eur J Cardiothorac Surg 1987; 1 : $55-58$.

13. Yung CM, Bessen SC, Hingorani V, Clements NC, Caruso AA. Idiopathic hemothorax. Chest 1993; 103: 638-639.

14. Oguzkaya F, Akcali Y, Bilgin M. Videothoracoscopy versus intrapleural streptokinase for management of post traumatic retained haemothorax: a retrospective study of 65 cases. Injury 2005; 36 : 526-529.

15. Meyer DM, Jessen ME, Wait MA, Estrera AS. Early evacuation of traumatic retained hemothoraces using thoracoscopy: a prospective, randomized trial. Ann Thorac Surg 1997; 64: 1396-400; discussion 1400-1.

16. Ahmed N, Jones D. Video-assisted thoracic surgery: state of the art in trauma care. Injury 2004; 35: 479-89.

17. Jerjes-Sanchez C, Ramirez-Rivera A, Elizalde JJ, Delgado R, Cicero $\mathrm{R}$, Ibarra-Perez $\mathrm{C}$, et al. Intrapleural fibrinolysis with streptokinase as an adjunctive treatment in hemothorax and empyema: a multicenter trial. Chest 1996; 109: 1514-9. 